\title{
PENGARUH WAKTU TINGGAL TERHADAP PRODUK FERROMANGAN HASIL SMELTING DALAM TANUR BUSUR LISTRIK MINI
}

\author{
Effect of Retention Time on the Ferromanganese Product of Smelting \\ in Mini Electric Arc Furnaces
}

\author{
YAYAT I. SUPRIYATNA ${ }^{1}$, ZULFIADI ZULHAN² dan FLORENTINUS FIRDIYONO \\ ${ }^{1}$ UPT. Balai Pengolahan Mineral Lampung - LIPI \\ Jalan Ir. Sutami Km.15 Tanjung Bintang - Lampung Selatan \\ Telp : (0721) 350054, Fax : (0721) 35005 \\ e-mail : yayat iman@yahoo.com \\ 2 Teknik Metalurgi - Institut Teknologi Bandung \\ Jalan Ganesha No.10 Bandung \\ ${ }^{3}$ Pusat Penelitian Metalurgi dan Material \\ Kawasan PUSPIPTEK Gedung 470 Cisauk - Tangerang Selatan
}

\begin{abstract}
ABSTRAK
Mangan merupakan elemen strategis yang memiliki beberapa aplikasi penting dalam dunia industri. Sampai saat ini $90 \%$ produksi mangan di dunia dikonsumsi oleh industri baja dalam bentuk ferromangan. Mangan sebagai unsur pemadu ditambahkan dengan tujuan untuk meningkatkan kekuatan, keuletan, kekerasan, mampu kerja dan ketahanan dari produk, khususnya baja. Kebutuhan ferromangan untuk pembuatan baja kasar adalah 10,6 kg FeMn/ton baja kasar. Sebagian besar dari kebutuhan ferromangan Indonesia dipenuhi melalui impor. Indonesia memiliki potensi cadangan mangan cukup besar tetapi berupa bijih mangan kadar rendah. Oleh karena itu, pada penelitian ini dipelajari proses pembuatan ferromangan dari bijih mangan lokal dengan reduktor kokas. Percobaan pendahuluan dilakukan untuk mempelajari pengaruh waktu tinggal terhadap proses pembuatan ferromangan dengan variasi waktu tinggal yaitu 40, 50, dan 60 menit dengan variabel tetap kokas $5,5 \mathrm{~kg}$, batu kapur $7,5 \mathrm{~kg}$ dan bijih mangan $30 \mathrm{~kg}$. Hasil terbaik dari percobaan pendahuluan diperoleh pada waktu proses 60 menit dengan produk ferromangan 4,5 $\mathrm{kg}$ dan kadar $69,69 \% \mathrm{Mn}$. Pengaruh waktu tinggal dipelajari lebih lanjut dengan varibel tetap kokas $8 \mathrm{~kg}$, batu kapur $7 \mathrm{~kg}$ dan bijih mangan $30 \mathrm{~kg}$ untuk setiap variasi waktu 60, 70 dan 90 menit. Produk dan terak hasil percobaan kemudian dianalisis menggunakan AAS dan OES. Hasil terbaik untuk variasi waktu tinggal yaitu 70 menit dengan hasil 6,95 kg FeMn, kadar 77,42\%Mn dan \% ekstraksi mangan 53,83\%. Hasil yang diperoleh menunjukan ferromangan dengan kadar $\mathrm{Mn} \geq 60 \%$ dapat dibuat dari bijh mangan kadar rendah Indonesia dalam tanur busur listrik mini pada tekanan atmosfer.
\end{abstract}

Kata kunci : Ferromangan, kokas, waktu tinggal, tanur busur listrik mini.

\begin{abstract}
Manganese is a strategic element that has several important applications in the industry. Until now, 90\% of manganese production is consumed by the steel industry in the form of ferromanganese. Manganese as an alloying element is added in order to increase strength, ductility, hardness, workability and the resilience of the products, particularly steel. Crude steel production needs $10.6 \mathrm{~kg}$ of ferromangan per ton crude steel. Almost all of Indonesia needs for manganese is supplied through imports. Potential reserves of manganese in Indonesia is quite large however mostly low grade. In this research, lowgrade manganese ore will be studied to make ferromanganese using coke as reducing agent. A series of experiments was conducted to study the
\end{abstract}


effect of retention time on the ferromanganese product. Preliminary experiments conducted using variations retention time $(40,50$, and 60 minutes) with a fixed amount of $5.5 \mathrm{~kg}$ coke, $7.5 \mathrm{~kg}$ limestone, $30 \mathrm{~kg}$ manganese ore. The best product of preliminary experiments was obtained in the processing time of 60 minutes with $4.5 \mathrm{~kg}$ ferromangan, and manganese contents was $69.69 \%$. Effect of retention time was studied further with fixed variable $8 \mathrm{~kg}$ of coke, $7 \mathrm{~kg}$ of limestone and $30 \mathrm{~kg}$ of manganese ore for every time variations of 60, 70 and 90 minutes. Products and slag are then analyzed using AAS and OES. The best results for the variation of the retention time is 70 minutes with resulted in $6.95 \mathrm{~kg} \mathrm{FeMn}, 77.42 \% \mathrm{Mn}$ and extracted manganese $53.83 \%$. The results showed ferromanganese with Mn content $\geq 60 \%$ can be made from lowgrade Indonesian manganese ore in the mini electric arc furnace at atmospheric condition.

Keywords: Ferromangan, coke, retention time, mini electric arc furnace.

\section{PENDAHULUAN}

Mangan merupakan elemen strategis yang memiliki beberapa aplikasi penting dalam dunia industri. Sampai saat ini, 90\% mangan hasil produksi dikonsumsi oleh industri baja dalam bentuk ferromangan, sisanya untuk produksi baterai kering, keramik, gelas, pewarna dan obat-obatan (http://www.majalahtambang.com, 2008).

Data yang dilansir Badan Geologi, Kementerian Energi dan Sumber Daya Mineral pada tahun 2010 menyebutkan bahwa sumberdaya mangan di Indonesia sebesar 10,62 juta ton berupa bijih dan 5,78 juta ton merupakan logam. Sementara cadangan yang ada 0,93 juta ton berupa bijih dan logam sebanyak 0,59 juta ton (http://www.majalahtambang.com, 2011). Namun, selama ini mangan lebih banyak diekspor dalam keadaan wantah tanpa diolah sendiri di dalam negeri. Hal ini bertolak belakang dengan Undang - Undang No 4 Tahun 2009 tentang kewajiban bagi Pemegang Izin Usaha Pertambangan (IUP) dan Izin Usaha Pertambangan Khusus (IUPK) untuk melakukan peningkatan nilai tambah produk tambang mineral dan batubara melalui kegiatan pengolahan dan pemurnian. Pada Pasal 103 ayat 1 dinyatakan bahwa "Pemegang IUP dan IUPK Operasi Produksi wajib melakukan pengolahan dan pemurnian hasil penambangan di dalam negeri" (UU RI No 4, 2009). Terkait dengan kegiatan peningkatan nilai tambah mineral melalui kegiatan pengolahan dan pemurnian tersebut diatur dan diperjelas lagi melalui Permen ESDM RI No 8 tahun 2015 tentang Peningkatan Nilai Tambah Mineral melalui Kegiatan Pengolahan dan Pemurnian Mineral yang isinya mengatur batasan minimum produk pengolahan dan/atau pemurnian untuk mineral logam dan non logam hasil tambang di dalam negeri. Batasan minimum pengolahan dan pemurnian mineral mangan sesuai dengan Lampiran I, Permen ESDM No. 8 Tahun 2015 di dalam negeri salah satunya berupa logam paduan ferromangan dengan kadar $\mathrm{Mn} \geq 60 \%$ (Permen ESDM No 8, 2015).

Ferromangan merupakan bentuk paduan antara unsur besi dan unsur mangan, dan mangan merupakan unsur yang dominan. Kandungan unsur mangan di dalam ferromangan pada umumnya berkisar antara 70\% - 90\% Mn (Supriyatna, 2013). Kandungan unsur-unsur lainnya dalam paduan ini antara lain karbon (C) hingga 7,5\%, Si hingga 3\%, P hingga 0,4\%, dan S hingga 0,05\%, selebihnya terdiri atas unsur besi (Fe). Klasifikasi yang lebih jelas dari ferromangan ini ditampilkan pada Tabel 1.

Kebutuhan mangan meningkat seiring dengan meningkatnya kebutuhan baja. Konsumsi baja merupakan salah satu indikator tingkat kemajuan dan kemakmuran suatu negara. Salah satu ferroalloy yang banyak digunakan untuk pembuatan baja adalah ferromangan (FeMn). Mangan sebagai unsur pemadu ditambahkan dengan tujuan untuk meningkatkan kekuatan, keuletan, kekerasan, mampu kerja dan ketahan dari produk, khususnya baja. Selain itu mangan mempunyai kemampuan sebagai deoxidizer dan desulfurizer (Cardakli, 2010). Konsumsi ferromangan tiap tahun diperkirakan terus meningkat karena didorong permintaan baja yang terus tumbuh lebih kurang 2 persen tiap tahun (http://www.majalahtambang.com, 2008).

Pembuatan ferromangan dapat dilakukan dengan dua cara yaitu menggunakan tanur tiup (blast furnace) dan tanur busur listrik (electric arc furnace) (Welebeloved, dkk., 2012). Bahan baku untuk kedua cara tersebut adalah bijih mangan. Sedangkan untuk pereduksi menggunakan kokas atau arang kayu, kemu- 
dian sebagai zat imbuh menggunakan batu kapur (limestone).

Reaksi reduksi yang tejadi pada unsur Mn dan Fe dalam proses pembuatan ferromangan (Olsen, dkk, 1995) adalah sebagai berikut:

$$
\begin{array}{ll}
\mathrm{MnO}_{2}(\mathrm{~s})+1 / 2 \mathrm{CO}(\mathrm{g}) & =1 / 2 \quad \mathrm{Mn}_{2} \mathrm{O}_{3(\mathrm{~s})}+1 / 2 \\
\mathrm{CO}_{2(\mathrm{~g})} & \Delta \mathrm{H}_{298}=-99,4 \mathrm{~kJ} \ldots . .(1) \\
\mathrm{Mn}_{2} \mathrm{O}_{3(\mathrm{~s})}+1 / 3 \mathrm{CO}(\mathrm{g}) & =2 / 3 \mathrm{Mn}_{3} \mathrm{O}_{4(\mathrm{~s})}+1 / 3 \\
\mathrm{CO}_{2(\mathrm{~g})} & \Delta \mathrm{H}_{298}=-66,5 \mathrm{~kJ} \ldots . .(2) \\
\mathrm{Mn}_{3} \mathrm{O}_{4(\mathrm{~s})}+\mathrm{CO}_{(\mathrm{g})} & =3 \mathrm{MnO}(\mathrm{s})+\mathrm{CO}_{2(\mathrm{~g})} \\
& \Delta \mathrm{H}_{298}=-51,2 \mathrm{~kJ} \ldots . .(3) \\
1 / 3 \mathrm{C}_{(\mathrm{s})}+1 / 3 \mathrm{CO}_{2(\mathrm{~g})} & =2 / 3 \mathrm{CO}(\mathrm{g}) \\
& \Delta \mathrm{H}_{298}=+57,5 \mathrm{~kJ} \ldots(4) \\
1 / 2 \mathrm{Fe}_{2} \mathrm{O}_{3(\mathrm{~s})}+3 / 2 \mathrm{CO}_{(\mathrm{g})} & =\mathrm{Fe}_{(\mathrm{s})}+3 / 2 \mathrm{CO}_{2(\mathrm{~g})} \\
& \Delta \mathrm{H}_{298}=-11,59 \mathrm{~kJ} \ldots(5) \\
1 / 2 \mathrm{Fe}_{2} \mathrm{O}_{3(\mathrm{~s})}+3 / 2 \mathrm{C}_{(\mathrm{s})} & =\mathrm{Fe}_{(\mathrm{s})}+3 / 2 \mathrm{CO}_{(\mathrm{g})} \\
& \Delta \mathrm{H}_{298}=+247,1 \mathrm{~kJ} .(6) \\
\mathrm{MnO}_{(\mathrm{l})}+\mathrm{C}_{(\mathrm{s})} & =\mathrm{Mn}_{(\mathrm{l})}+\mathrm{CO}_{(\mathrm{g})} \\
& \Delta \mathrm{H}_{298}=+236,4 \mathrm{~kJ} .(7) \\
\mathrm{SiO}_{2(\mathrm{l})}+2 \mathrm{C}_{(\mathrm{s})} & =\mathrm{Si}_{(\mathrm{l})}+2 \mathrm{CO}_{(\mathrm{g})} \\
& \Delta \mathrm{H}_{298}=+725,9 \mathrm{~kJ} .(8)
\end{array}
$$

Reaksi (1), (2), (3) dan (5) merupakan reaksi eksotermik dan reaksi (4), (6), (7) dan (8) merupakan reaksi endotermik. Berdasarkan reaksi-reaksi di atas jumlah nilai reaksi endotermik lebih besar dibandingkan reaksi eksotermik sehingga membutuhkan energi yang lebih besar dalam proses peleburan.

Penelitian terkait pembuatan ferromangan yang telah dilakukan sebelumnya ditampilkan pada Tabel 2.

Hasil penelitian-penelitian di atas menunjukkan waktu dan temperatur sangat berpengaruh dalam proses smelting bijih mangan menjadi ferromangan. Namun, penelitian-penelitian tersebut menggunakan muffle furnace untuk pro- ses pembuatan ferromangannya sedangkan data penelitian pembuatan ferromangan dengan menggunakan tanur busur listrik masih sangat jarang, khususnya pembuatan ferro-mangan dari bijih mangan Indonesia.

Oleh karena itu, pada penelitian ini membahas pembuatan ferromangan dari bijih mangan kadar rendah Indonesia dalam tanur busur listrik. Fokus penelitian ini adalah untuk mengetahui pengaruh waktu tinggal terhadap proses pembuatan ferromangan. Parameter proses yang dilihat adalah produk ferromangan yang dihasilkan, kadar mangan dalam produk, \% ekstraksi mangan serta komposisi produk.

\section{METODE}

Secara garis besar percobaan ini meliputi beberapa tahap percobaan sebagai berikut :

1. Preparasi dan analisis bijih mangan, batu kapur, dan kokas sebagai bahan baku untuk pembuatan ferromangan.

2. Perhitungan neraca massa sebagai dasar dalam penentuan komposisi umpan masuk dalam percobaan pendahuluan.

3. Percobaan pembuatan ferromangan dengan variasi waktu tinggal.

4. Analisis terhadap produk dan terak yang diperoleh dari hasil percobaan untuk melihat pengaruh variasi yang dilakukan.

Bijih mangan dan batu kapur yang diperoleh masih dalam bentuk bongkahan sehingga perlu dilakukan pengecilan ukuran melalui proses penghancuran. Proses penghancuran menggunakan mesin jaw crusher sehingga diperoleh bijih mangan dan batu kapur dengan ukuran 1$3 \mathrm{~cm}$. Kokas juga dilakukan penghancuran sehingga diperoleh ukuran yang hampir sama.

Tabel 1. Klasifikasi ferromangan menurut standar ASTM (ASTM, 1993)

\begin{tabular}{lccccccccc}
\hline \multirow{2}{*}{$\begin{array}{c}\text { Kadar } \\
(\%)\end{array}$} & \multicolumn{2}{c}{$\begin{array}{c}\text { Ferromangan } \\
\text { kadar karbon } \\
\text { rendah }\end{array}$} & \multicolumn{3}{c}{$\begin{array}{c}\text { Ferromangan } \\
\text { kadar karbon medium }\end{array}$} & \multicolumn{2}{c}{$\begin{array}{c}\text { Ferromangan standar } \\
\text { (kadar karbon tinggi) }\end{array}$} \\
\cline { 2 - 9 } & $\begin{array}{c}\text { Kelas } \\
\end{array}$ & Kelas & Kelas & Kelas & Kelas & Kelas & Kelas & Kelas & Kelas \\
& A & B & A & B & C & D & A & B & C \\
\hline Mn & $85-90$ & $80-85$ & $80-85$ & $80-85$ & $80-85$ & $80-85$ & $78-82$ & $76-78$ & $74-76$ \\
C (maks) & 0,75 & 0,75 & 1,50 & 1,50 & 1,50 & 1,50 & 7,50 & 7,50 & 7,50 \\
Si (maks) & 2,00 & $5-7$ & 1,50 & 1,00 & 0,70 & 0,53 & 1,20 & 1,20 & 1,20 \\
P (maks) & 0,20 & 0,30 & 0,30 & 0,30 & 0,30 & 0,30 & 0,35 & 0,35 & 0,35 \\
S (maks) & 0,02 & 0,02 & 0,02 & 0,02 & 0,02 & 0,02 & 0,05 & 0,05 & 0,05 \\
\hline
\end{tabular}


Tabel 2. Penelitian pembuatan ferromangan yang pernah dilakukan (Cardakli, 2010) dan (Akil, 2007)

\begin{tabular}{|c|c|}
\hline Referensi & Penelitian \\
\hline Emeksiz, F., (1991) & $\begin{array}{l}\text { Mempelajari pembuatan ferromangan kadar karbon tinggi menggunakan bijih } \\
\text { mangan kadar tinggi }(41 \% \mathrm{Mn}) \text { yang berasal dari Denizli - Tavaz, kokas, batu } \\
\text { kapur, besi skrap dan fluorspar dalam krusibel grafit pada temperatur } 1600^{\circ} \mathrm{C} \text {. } \\
\text { Waktu dan rasio kokas/bijih mangan sebagai variabel percobaan. }\end{array}$ \\
\hline Imer, S.T., (1997) & $\begin{array}{l}\text { Mempelajari pembuatan ferromangan menggunakan bijih mangan Denizli - } \\
\text { Tavas berkadar } 31 \% \mathrm{Mn} \text {. Proses smelting menggunakan kokas, batu kapur, } \\
\text { fluorspar dan besi skrap dilakukan dalam krusibel grafit pada temperatur } \\
1600^{\circ} \mathrm{C} \text {. Waktu dan penambahan CaF sebagai parameter percobaan. }\end{array}$ \\
\hline Kalfaoglu, F., (1997) & $\begin{array}{l}\text { Mempelajari proses reduksi bijih mangan dari Denizli Tavas menggunakan grafit. } \\
\text { Percobaan dilakukan pada suhu } 1100^{\circ} \mathrm{C}, 1150^{\circ} \mathrm{C}, 1200^{\circ} \mathrm{C}, 1250^{\circ} \mathrm{C} \text { dan } \\
1300^{\circ} \mathrm{C} \text {. Percobaan dilakukan dalam argon athmosfir. }\end{array}$ \\
\hline Keskinkilic, E., (2001) & $\begin{array}{l}\text { Mempelajari pembuatan silikomangan menggunakan bijih mangan dari Denizli - } \\
\text { Tavas, karbon aktif, } \mathrm{CaO} \text { dan kuarsa dalam krusibel grafit dalam muffle furnace. } \\
\text { Waktu 1, } 1,5 \text { dan } 3 \text { jam dan temperatur } 1600^{\circ} \mathrm{C}, 1650^{\circ} \mathrm{C} \text { dan } 1700^{\circ} \mathrm{C} \text { sebagai } \\
\text { parameter percobaan yang digunakan. }\end{array}$ \\
\hline Akil, C., (2007) & $\begin{array}{l}\text { Melakukan penelitian untuk mencari kondisi optimal produksi mangan dan besi } \\
\text { karbida menggunakan bijih mangan dari Denizli - Tavas melalui proses reduksi } \\
\text { kondisi padat. Efek temperatur, waktu, jumlah penambahan karbon aktif dan } \\
\mathrm{CaO} \text { sebagai variasi percobaan. }\end{array}$ \\
\hline Cardakli, I.S., (2010) & $\begin{array}{l}\text { Penelitian dilakukan untuk mempelajari pembuatan ferromangan kadar karbon } \\
\text { tinggi dari bijih mangan Erzincan. Proses smelting dilakukan dalam muffle } \\
\text { furnace. Variasi waktu, basisitas bahan masuk, penambahan CaF dan rasio kokas } \\
\text { dilakukan dalam penelitian ini. }\end{array}$ \\
\hline
\end{tabular}

Komposisi kimia dari bijih mangan dan batu kapur ditentukan menggunakan XRF. Percontoh bijih mangan dan batu kapur terlebih dahulu dihaluskan hingga ukuran -200 mesh menggunakan ball mill. Tabel 3 dan Tabel 4 menunjukan hasil analisis XRF untuk bijih mangan dan batu kapur. Analisis XRD dilakukan untuk mengetahui senyawa dominan apa saja yang ada di dalam bijih mangan. Reduktor kokas dihaluskan hingga ukuran -200 mesh, kemudian dianalisis proksimat. Tabel 5 menunjukkan hasil analisis terhadap reduktor.

Perhitungan neraca massa dilakukan menggunakan aplikasi excell dengan menggunakan data hasil analisis bahan baku, kapasitas produksi yang diinginkan, reaksi kimia yang terlibat dalam proses reduksi dan peleburan bijih mangan menjadi ferromangan yang ada dalam literatur.

Percobaan dilakukan dalam tanur busur listrik mini dengan spesifikasi teknis sebagai berikut :

- furnace chamber : diameter dalam 41,5 $\mathrm{cm}$ dan tinggi $27 \mathrm{~cm}$

- trafo : kapasitas 250KVA, outBachtiput sekunder 65V, 3 Phase/50 Hz

- elektroda : diameter $3 \mathrm{~cm}$, panjang $80 \mathrm{~cm}$
Percobaan pendahuluan dilakukan untuk menentukan waktu tinggal pada proses pembuatan ferromangan. Variabel waktu yang digunakan yaitu 40 menit, 50 menit dan 60 menit sedang variabel lain yaitu jumlah reduktor dan jumlah penambahan fluks dibuat tetap. Lama waktu tinggal dalam percobaan ini adalah lamanya proses peleburan dari awal hingga dilakukan pengeluaran produk logam cair. Setelah diperoleh rasio batu kapur dan reduktor terbaik kemudian dilakukan kembali percobaan untuk mengetahui waktu tinggal terbaik.

\section{HASIL DAN PEMBAHASAN}

\section{Hasil Analisis Bahan Baku}

Hasil analisis XRF bijih mangan dan batu kapur ditampilkan pada Tabel 3 dan 4. Berdasarkan komposisi hasil analisis menunjukan bijih mangan yang digunakan termasuk ke dalam jenis bijih mangan jenis ferruginous manganese ore tetapi dengan kandungan silika yang tinggi. Jenis bijih mangan ini memiliki kandungan $25<M n<35$ (Bureau of Indian Standard, 2006). Hasil analisis XRD ditampilkan pada Gambar 1. Hasil analisis XRD menunjukkan bahwa senyawa yang paling dominan dalam bijih tersebut adalah pirolusit $\left(\mathrm{MnO}_{2}\right)$. 
Terdeteksi juga senyawa-senyawa lain yang dominan di antaranya $\mathrm{SiO}_{2}, \mathrm{Fe}_{2} \mathrm{O}_{3}$ dan $\mathrm{CaCO}_{3}$.

Tabel 3. Hasil analisis XRF percontoh bijih mangan yang digunakan dalam penelitian

\begin{tabular}{llccr}
\hline No & Senyawa & $\begin{array}{c}\text { Jumlah } \\
\text { (\% berat) }\end{array}$ & Unsur & $\begin{array}{c}\text { Jumlah } \\
\text { (\% berat) }\end{array}$ \\
\hline 1 & $\mathrm{MnO}_{2}$ & 52,7 & $\mathrm{Mn}$ & 33,3414 \\
2 & $\mathrm{SiO}_{2}$ & 29,11 & $\mathrm{Si}$ & 13,5847 \\
3 & $\mathrm{Al}_{2} \mathrm{O}_{3}$ & 2,46 & $\mathrm{Al}$ & 1,3024 \\
\hline 4 & $\mathrm{Fe}_{2} \mathrm{O}_{3}$ & 8,17 & $\mathrm{Fe}$ & 5,7190 \\
5 & $\mathrm{TiO}_{2}$ & 0,12 & $\mathrm{Ti}$ & 0,0720 \\
6 & $\mathrm{~K}_{2} \mathrm{O}$ & 1,06 & $\mathrm{~K}$ & 0,8796 \\
7 & $\mathrm{CaO}$ & 2,67 & $\mathrm{Ca}$ & 1,9071 \\
8 & $\mathrm{MgO}$ & 0,57 & $\mathrm{Mg}$ & 0,3420 \\
9 & $\mathrm{Cr} 2 \mathrm{O}_{3}$ & 1,36 & $\mathrm{Cr}$ & 0,9305 \\
10 & $\mathrm{P}_{2} \mathrm{O}_{5}$ & 0,16 & $\mathrm{P}$ & 0,0699 \\
11 & $\mathrm{CuO}$ & 0,071 & $\mathrm{Cu}$ & 0,0568 \\
12 & $\mathrm{BaO}_{13}$ & 0,59 & $\mathrm{Ba}$ & 0,5283 \\
14 & $\mathrm{SO}_{3}$ & 0,003 & $\mathrm{~S}$ & 0,0012 \\
15 & $\mathrm{Co} 2 \mathrm{O}_{3}$ & 0,001 & $\mathrm{Co}$ & 0,0711 \\
16 & $\mathrm{NiO}_{1 b}$ & 0,002 & $\mathrm{Ni}$ & 0,0016 \\
17 & $\mathrm{ZnO}_{18}$ & 0,59 & $\mathrm{~Pb}$ & 0,5477 \\
19 & $\mathrm{SrO}_{2} \mathrm{O}_{3}$ & 0,24 & $\mathrm{Zn}$ & 0,1926 \\
\hline
\end{tabular}

Tabel 4. Hasil analisis XRF percontoh batu kapur yang digunakan dalam penelitian

\begin{tabular}{llllr}
\hline No & Senyawa & $\begin{array}{l}\text { Jumlah } \\
\text { (\% berat) }\end{array}$ & Unsur & $\begin{array}{l}\text { Jumlah } \\
\text { (\% berat) }\end{array}$ \\
\hline 1 & $\mathrm{CaO}$ & $55,65 \%$ & $\mathrm{Ca}$ & 39,75 \\
2 & $\mathrm{SiO}_{2}$ & $0,13 \%$ & $\mathrm{Si}$ & 0,06 \\
3 & $\mathrm{Al}_{2} \mathrm{O}_{3}$ & $0,22 \%$ & $\mathrm{Al}$ & 0,12 \\
4 & $\mathrm{Fe}_{2} \mathrm{O}_{3}$ & $0,20 \%$ & $\mathrm{Fe}$ & 0,14 \\
5 & $\mathrm{MgO}$ & $0,01 \%$ & $\mathrm{Mg}$ & 0,01 \\
6 & $\mathrm{MnO}$ & $0,63 \%$ & $\mathrm{Mn}$ & 0,49 \\
7 & $\mathrm{Na} 2 \mathrm{O}$ & $0,01 \%$ & $\mathrm{Na}$ & 0,01 \\
8 & $\mathrm{~K} 2 \mathrm{O}$ & $0,04 \%$ & $\mathrm{~K}$ & 0,03 \\
9 & $\mathrm{TiO}_{2}$ & $0,03 \%$ & $\mathrm{Ti}$ & 0,02 \\
10 & $\mathrm{P}_{2} \mathrm{O}_{5}$ & $0,02 \%$ & $\mathrm{P}$ & 0,01 \\
11 & $\mathrm{SO}_{3}$ & $0,00 \%$ & $\mathrm{~S}$ & 0,00 \\
12 & $\mathrm{LOI}$ & $43,06 \%$ & $\mathrm{LOI}$ & 43,06 \\
\hline
\end{tabular}

\section{Hasil Percobaan}

Pada percobaan ini variabel yang dipelajari adalah waktu tinggal cairan logam dalam tanur busur listrik. Waktu tinggal pada percobaan pendahuluan dilakukan pada rentang waktu 40 menit, 50 menit, dan 60 menit dengan variabel tetap kokas (K) 5,5 kg, batu kapur (BK) 7,5 kg dan bijh mangan (BM) $30 \mathrm{~kg}$. Pengaruh waktu tinggal dipelajari kembali dengan melakukan percobaan menggunakan komposisi bahan baku yang digunakan yaitu kokas $8 \mathrm{~kg}$, batu kapur $7 \mathrm{~kg}$ dan bijih mangan $30 \mathrm{~kg}$. Variasi waktu yang digunakan yaitu 60 menit, 70 menit dan 90 menit. Data percobaan dan hasil ditampilkan pada Tabel 6 .

Tabel 5. Hasil analisis proksimat kokas yang digunakan (basis : adb)

\begin{tabular}{clc}
\hline No & Analisis Proksimat & Kokas \\
\hline 1 & FC (\%) & 81,04 \\
2 & VM (\%) & 2,88 \\
3 & Ash (\%) & 15,41 \\
4 & Moisture (\%) & 0,67 \\
\hline
\end{tabular}

Percobaan pendahuluan hasilnya mengindikasikan seiring bertambahnya waktu tinggal maka produk ferromangan dan kadar Mn yang didapat semakin meningkat. Hasil terbaik diperoleh pada waktu tinggal 60 menit yang menghasilkan produk ferromangan $4,5 \mathrm{~kg}$ dengan kadar 69,69\%Mn seperti yang ditampilkan pada Gambar 2. Pengaruh waktu tinggal dipelajari kembali dengan melakukan percobaan menggunakan komposisi bijih mangan 30 kg, kokas 8 kg dan batu kapur 7 kg. Hasil yang diperoleh kecenderungannya hampir sama dengan ujicoba pendahuluan yaitu seiring bertambahnya waktu tinggal maka produk ferromangan yang diperoleh semakin bertambah. Waktu tinggal 70 menit menghasilkan produk ferromangan sebesar 6,95 kg dengan kadar $77,42 \% \mathrm{Mn}$ merupakan hasil terbaik (Gambar 2).

Gambar 2 menunjukkan bahwa seiring bertambahnya waktu tinggal dari 40 sampai dengan 70 menit maka produk ferromangan yang diperoleh semakin bertambah. Namun, untuk waktu tinggal 90 menit produk ferromangan yang diperoleh sedikit lebih rendah (Gambar 2). Jika melihat pada neraca massa hasil percobaan, pada waktu tinggal 90 menit untuk unsur Mn dan Fe yang hilang secara berurutan yaitu sebesar 3,322 kg dan 1,346 sehingga mengurangi berat produk (Gambar 2) dan terak (Gambar 3) yang diperoleh. Kehilangan tersebut mungkin terjadi saat proses penuangan yang tidak sempurna sehingga masih ada sedikit lelehan yang tertinggal dan menempel dalam tanur atau mungkin ada sebagian yang 
menguap dikarenakan temperatur dari busur (arc) yang tinggi ( $>5000 \mathrm{~K})$. Temperatur didih mangan dan besi secara berurutan yaitu $2334 \mathrm{~K}$ dan 3135K. Kemungkinan penguapan logam mangan dan besi dikarenakan temperatur busur (arc) yang lebih besar dari temperatur didih logam tersebut semakin besar seiring bertambahnya waktu tinggal.

Tabel 6. Data hasil percobaan

\begin{tabular}{lcccccc}
\hline \multirow{2}{*}{ Keterangan } & \multicolumn{3}{c}{ Ujicoba Pendahuluan } & \multicolumn{3}{c}{ Variabel Rasio Reduktor } \\
\cline { 2 - 7 } & 1 & 2 & 3 & 4 & 5 & 6 \\
\hline Bijih mangan [BM] (Kg) & 30 & 30 & 30 & 30 & 30 & 30 \\
Kokas [K] (Kg) & 5,5 & 5,5 & 5,5 & 8 & 8 & 8 \\
Batu Kapur [BK] (Kg) & 7,5 & 7,5 & 7,5 & 7 & 7 & 7 \\
Waktu tinggal (menit) & 40 & 50 & 60 & 60 & 70 & 90 \\
$\%$ Ektraksi Mn & 7,66 & 14,14 & 31,38 & 49,22 & 53,83 & 38,31 \\
Terak (kg) & 31,50 & 25,10 & 23,75 & 15,55 & 12,30 & 10,50 \\
Produk FeMn & 1,90 & 2,50 & 4,50 & 6,6 & 6,95 & 4,60 \\
\hline Komposisi : & & & & & & \\
$\% M n$ & 40,29 & 56,55 & 69,69 & 74,54 & 77,42 & 83,23 \\
$\% \mathrm{C}$ & 4,35 & 4,24 & 2,55 & 2,72 & 2,34 & 1,33 \\
$\% \mathrm{Si}$ & 0,34 & 0,47 & 6,1 & 4,4 & 4,78 & 6,36 \\
$\% \mathrm{P}$ & 0,45 & 0,07 & 0,02 & 0,2 & 0,01 & 0,01 \\
$\% \mathrm{~S}$ & $<0,0002$ & $<0,0002$ & $<0,0002$ & $<0,0002$ & $<0,0002$ & $<0,0002$ \\
$\% \mathrm{Fe}$ & 53,29 & 36,73 & 20,42 & 16,71 & 14,09 & 7,97 \\
\hline
\end{tabular}

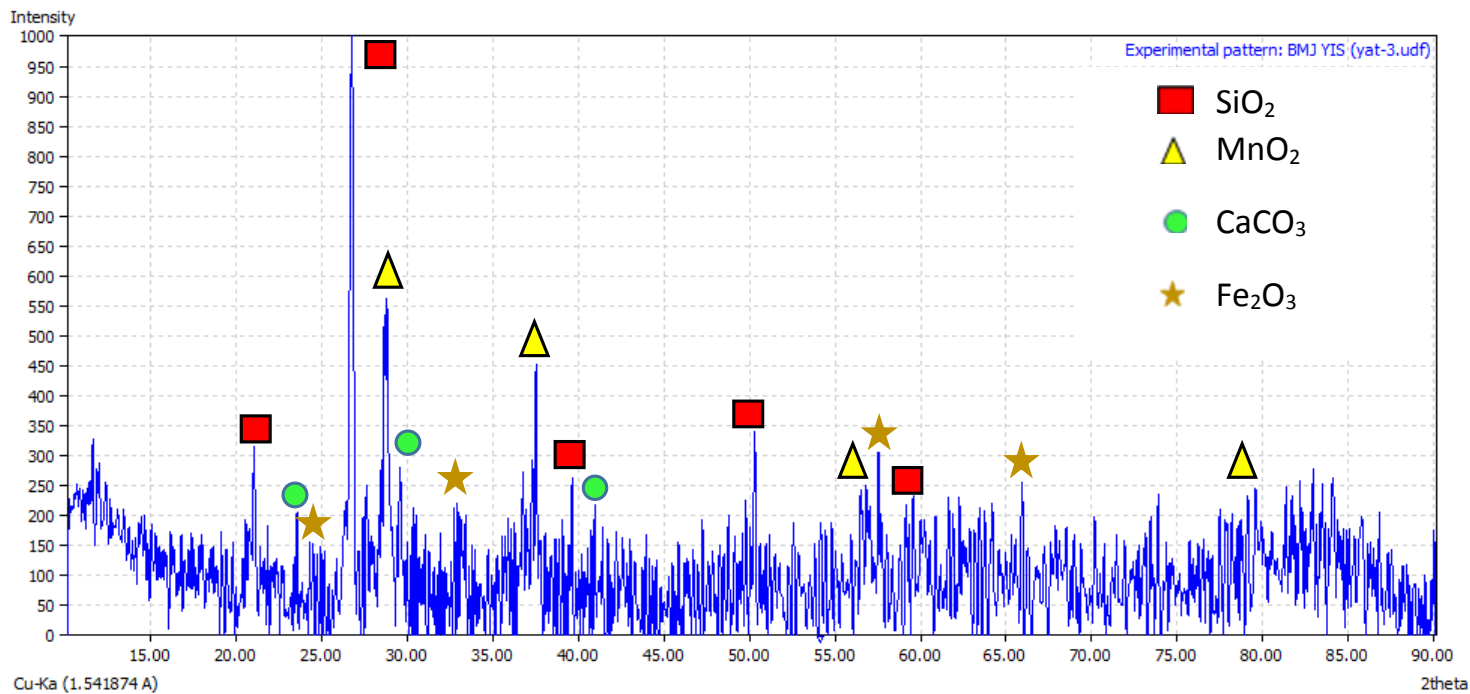

Gambar 1. Hasil analisis XRD pada percontoh bijih mangan 


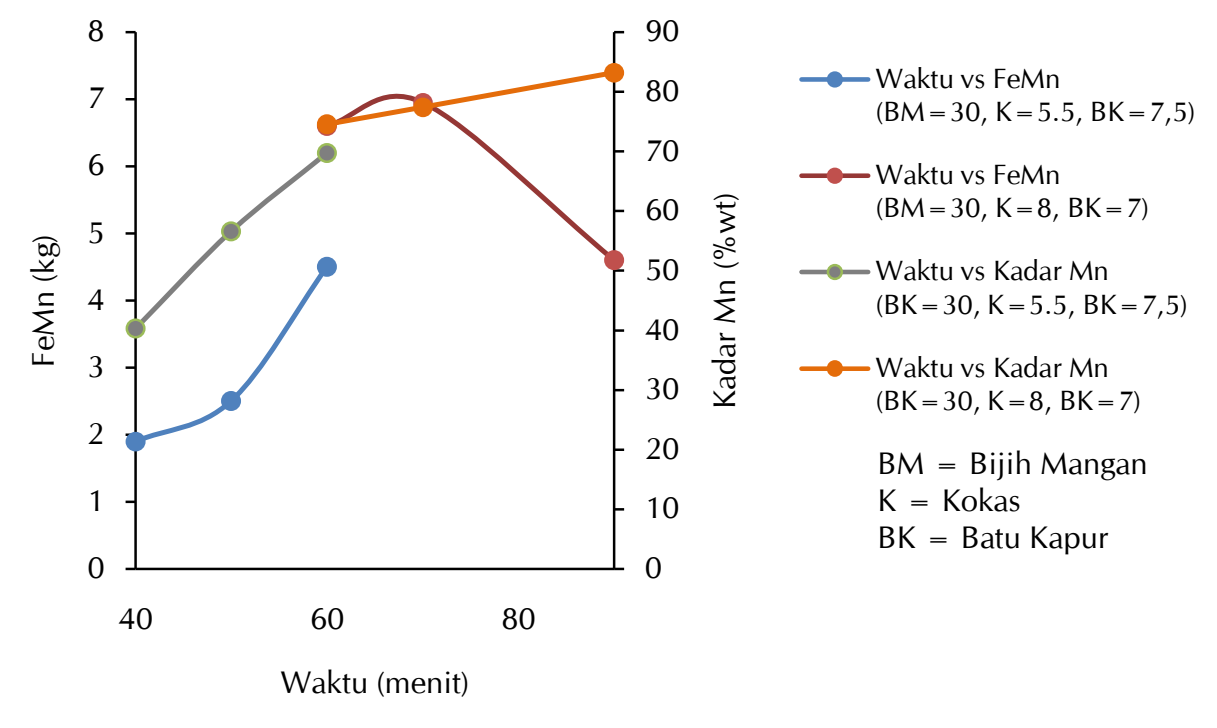

Gambar 2. Pengaruh waktu terhadap produk FeMn dan kadar Mn

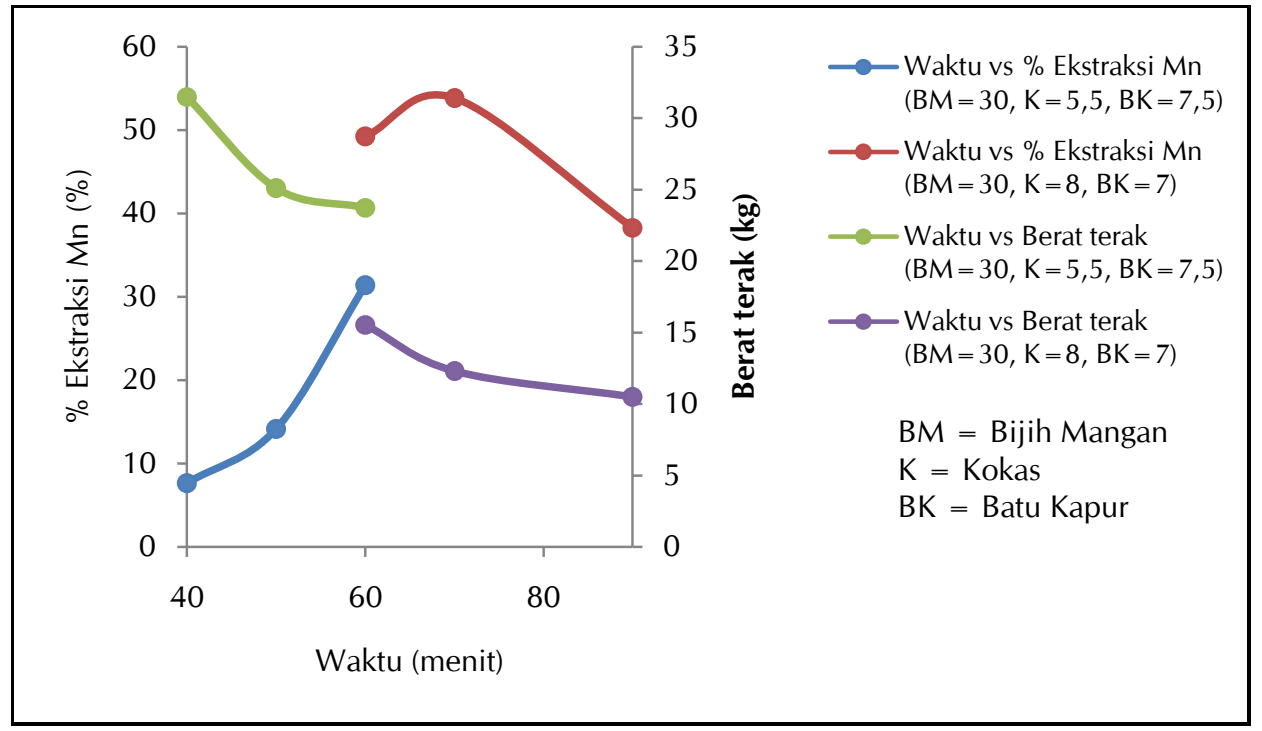

Gambar 3. Pengaruh waktu terhadap \% ekstraksi Mn dan berat terak

Gambar 4 menampilkan tekanan uap logam sebagai fungsi temperatur. Mangan dan besi pada temperatur yang sama untuk menguap memerlukan tekanan uap yang berbeda. Mangan dapat menguap pada temperatur $2000^{\circ} \mathrm{C}$ dengan tekanan \pm 1 atm (no.1) seperti ditunjukkan pada Gambar 4. Besi pada temperatur yang sama dapat menguap pada tekanan yang lebih rendah dari 1 atm (no.2). Oleh karena itu, pada temperatur dan tekanan yang sama jumlah mangan yang menguap dapat lebih banyak dibandingkan besi. Banyak- nya mangan dan besi yang menguap akan mengurangi jumlah produk ferromangan yang diperoleh.

Persentase ekstraksi mangan sebagai fungsi waktu ditampilkan pada Gambar 3. Hasil yang diperoleh pada percobaan pendahuluan (bijih mangan $30 \mathrm{~kg}$, kokas 5,5 kg dan batu kapur 7,5 kg) menunjukkan kecenderungan yang sama dengan kadar mangan dan berat produk ferromangan yang dihasilkan. Waktu 
tinggal semakin lama maka persentase ekstraksi mangan cenderung meningkat.

Pengaruh waktu proses terhadap komposisi produk ferromangan ditampilkan pada Gambar 5 dan Gambar 6. Kadar Mn dan Si seiring bertambahnya waktu proses menunjukkan kecenderungan meningkat kadarnya sedangkan Fe cenderung berkurang kadarnya. Namun peningkatan kadar $\mathrm{Si}$ lebih rendah daripada $\mathrm{Mn}$. Hal ini disebabkan $\mathrm{SiO}_{2}$ lebih stabil dari $\mathrm{MnO}$, sedangkan $\mathrm{FeO}$ paling tidak stabil jika dibandingkan $\mathrm{SiO}_{2}$ dan $\mathrm{MnO}$. Gambar 5 dan 6 menunjukkan kadar Si dalam produk pada waktu proses 60 menit, 70 menit dan 90 menit lebih besar dibandingkan pada waktu proses 40 menit, 50 menit dan 60 menit. Hal ini dapat disebabkan oleh jumlah kokas pada percobaan dengan waktu proses 60, 70 dan 90 menit (8 $\mathrm{kg}$ kokas) lebih besar dibandingkan kokas yang ditambahkan pada waktu proses 40, 50 dan 60 menit $(5,5 \mathrm{~kg}$ kokas). Jumlah kokas yang lebih banyak akan menambah ketersediaan karbon sehingga memungkinkan reaksi reduksi $\mathrm{SiO}_{2}$ menjadi $\mathrm{Si}$ oleh karbon dapat berlangsung seperti yang ditampilkan pada persamaan (9).

$$
\begin{aligned}
\mathrm{SiO}_{2}(1)+2 \mathrm{C}_{(\mathrm{s})}=\mathrm{Si}(\mathrm{l})+2 \mathrm{CO}_{(\mathrm{g})} \\
\Delta \mathrm{H}_{298}=+754,9 \mathrm{~kJ}
\end{aligned}
$$

Kadar Mn yang diperoleh untuk waktu proses lebih dari 60 menit memenuhi standar minimal untuk jenis ferromangan kadar karbon tinggi grade C yaitu $74-76 \% \mathrm{Mn}$ (Tabel 1 ). Kadar Si belum memenuhi standar karena pada produk yang diperoleh hasilnya yaitu $4,4-6,36 \%$. Standar maksimal kadar Si dalam produk ferromangan yaitu $1,2 \%$ untuk jenis ferromangan kadar karbon tinggi.

Unsur karbon (C) berdasarkan Gambar 5 dan Gambar 6 cenderung menurun seiring bertambahnya waktu proses. Kecenderungan kadar karbon yang menurun ini disebabkan kelarutan karbon dalam sistem $\mathrm{Fe}-\mathrm{Mn}-\mathrm{Si}-$ $\mathrm{C}$ menurun dengan meningkatnya kadar $\mathrm{Si}$ dalam logam seperti yang ditampilkan pada Gambar 7.

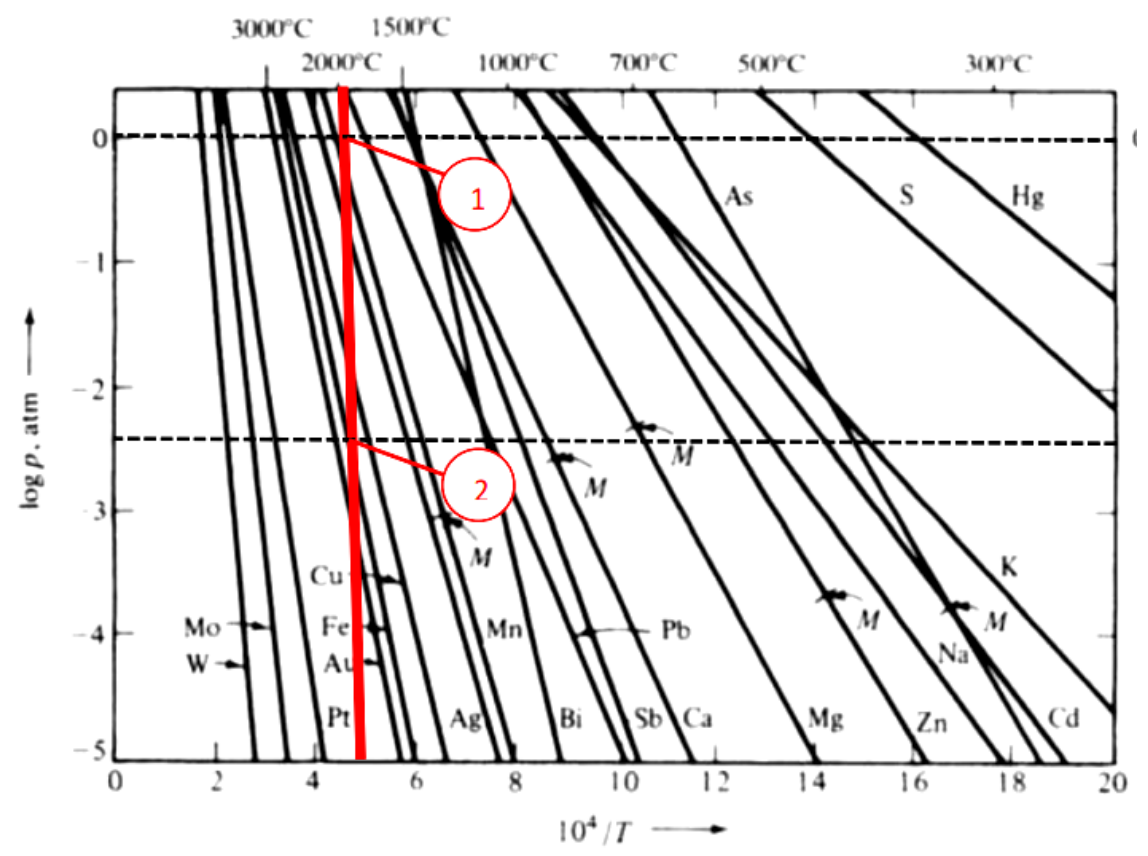

Gambar 4. Tekanan uap beberapa logam ( $M=$ Temperatur leleh) (Rosenqvist, 2004) 
Pengaruh Waktu Tinggal terhadap Produk Ferromangan Hasil Smelting ... Yayat I. Supriyatna dkk.

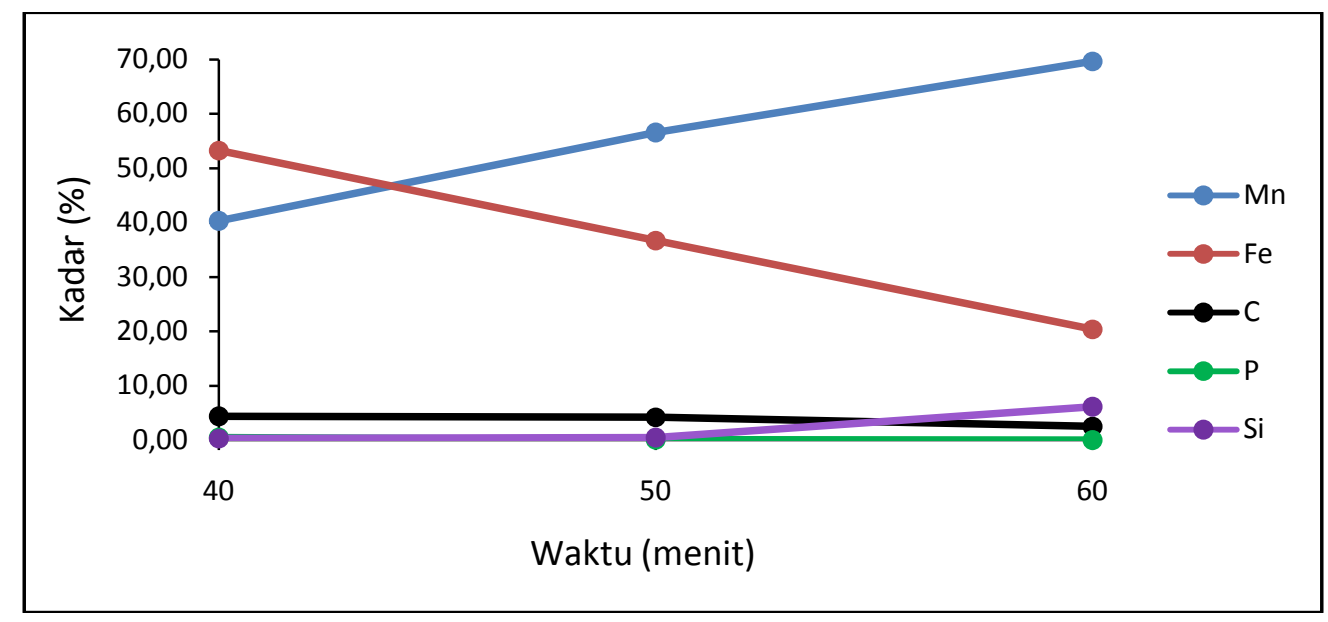

Gambar 5. Pengaruh waktu terhadap komposisi produk FeMn pada komposisi bijih mangan $30 \mathrm{~kg}$, kokas 5,5 kg dan batu kapur 7,5 kg

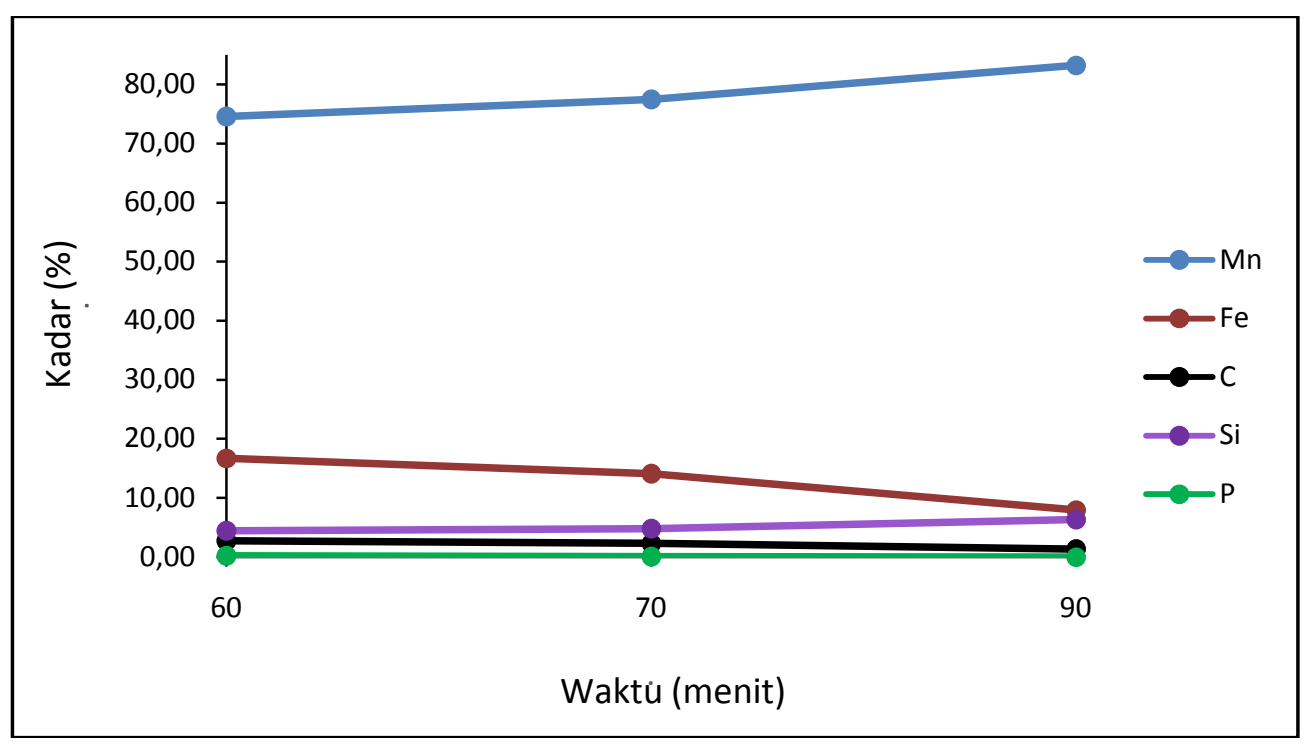

Gambar 6. Pengaruh waktu terhadap komposisi produk FeMn pada komposisi bijih mangan $30 \mathrm{~kg}$, kokas $8 \mathrm{~kg}$ dan batu kapur $7 \mathrm{~kg}$

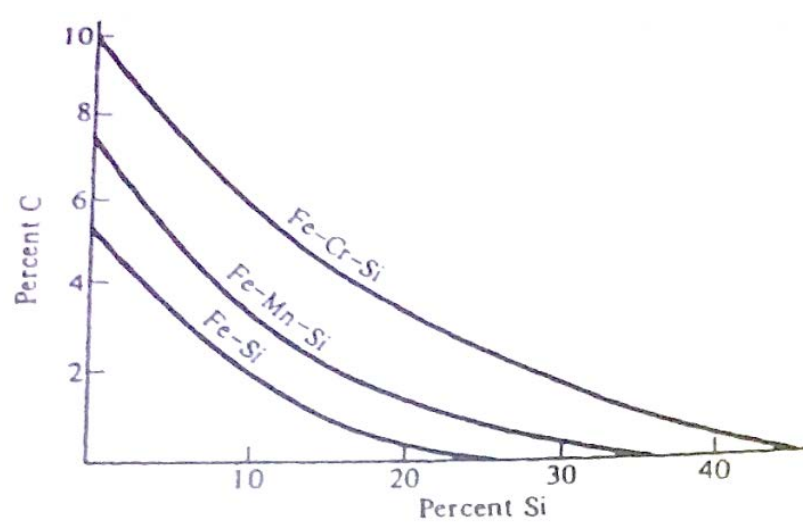

Gambar 7. Kelarutan karbon pada ferroalloys (Rosenqvist, 2004) 
Kadar Fe semakin berkurang dengan bertambahnya waktu seperti ditunjukkan pada Gambar 5 dan Gambar 6. Penurunan kadar Fe terjadi drastis pada selang waktu 40 sampai dengan 60 menit sedangkan pada selang waktu 60 menit sampai dengan 90 menit berkurang tidak begitu signifikan. Berkurangnya kadar Fe dalam produk ferromangan ini sebenarnya dikarenakan kadar Mn yang semakin meningkat. Jumlah Fe pada bahan baku terbatas hanya 5,72\% sedangkan kadar Mn dalam bahan baku 33,34\%. Saat FeO telah tereduksi menjadi Fe, baru terjadi proses reduksi MnO menjadi Mn. Seiring bertambahnya kadar Mn dalam produk ferromangan maka kadar Fe akan menurun.

Kadar fosfor dan sulfur pada bahan baku yang rendah menyebabkan kadar fosfor dan sulfur pada produk juga rendah dan memenuhi standar jenis ferromangan yaitu $\mathrm{P}=0,2$ - 0,35\% (maksimal) dan $\mathrm{S}=0,02-0,05 \%$ (maksimal).

\section{KESIMPULAN DAN SARAN}

\section{Kesimpulan}

Berdasarkan hasil percobaan dan analisis dapat diambil beberapa kesimpulan sebagai berikut :

1. Ferromangan dengan kadar $M n \geq 60 \%$ dapat dibuat dari bijih mangan kadar rendah Indonesia menggunakan reduktor kokas.

2. Hasil percobaan menunjukkan bahwa waktu tinggal 70 menit merupakan waktu terbaik dengan hasil 6,95 $\mathrm{kg} F \mathrm{FeMn}$ $(77,42 \% \quad \mathrm{Mn}, \quad 2,34 \% \quad \mathrm{C}, 4,78 \% \quad \mathrm{Si}$, $0,0143 \% \mathrm{P},<0,0002 \% \mathrm{~S}$ dan $14,09 \% \mathrm{Fe})$ dan persentase ekstraksi mangan 53,83\% pada komposisi bahan baku $30 \mathrm{~kg}$ bijih mangan, 8 kg kokas dan 7 kg batu kapur.

3. Produk ferromangan terbaik mendekati spesifikasi ferromangan standar (kadar karbon tinggi) kelas B, hanya kandungan Si-nya yang masih melebihi batas maksimal yaitu $1,2 \%$ Si.

\section{Saran}

1. Perlu dilakukan pengolahan terlebih dahulu terhadap bijih mangan untuk meningkatkan kadar mangan dan mengurangi kadar silika agar perolehan mangan meningkat dan kadar silika berkurang dalam produk.

2. Reduktor dapat menggunakan biomassa seperti cangkang sawit yang keberadaannya cukup melimpah di Indonesia.

\section{UCAPAN TERIMA KASIH}

Ucapan terima kasih disampaikan kepada UPT Balai Pengolahan Mineral Lampung LIPI yang telah mendanai dan mendukung kegiatan penelitian ini sehingga dapat terselesaikan dengan baik.

\section{DAFTAR PURTAKA}

Akıl C., 2007. Optimization of conditions to produce manganese and iron carbides from Denizli-Tavas manganese ore by solid state reduction, Master Of Science Thesis in Metallurgical and Materials Engineering Department, Middle East Technical University, Ankara, 2 - 30.

American Society for Testing and Materials (ASTM), 1993. Annual Book of ASTM Standards - Ferrous Castings; Ferroalloys, Volume 01.02, 59-61.

Bureau of Indian Standards, 2006. Classification of manganese ore, ferruginous manganese ore, siliceous manganese ore, dioxide manganese ore and manganiferrous iron, New Delhi, 12.

Cardakli, I.S., 2010. Production of high carbon ferromanganese from a manganese ore located in Erzincan, Tesis Program Magister, Midle East Technical University, 3- 29.

http://www.majalahtambang.com, 2011. Mangan menunggu peletakan batu kedua, diakses tanggal 10 Oktober 2014 pukul 01.00.

http://www.majalahtambang.com, 2008. Mangan menguntit industri baja, diakses tanggal 10 Oktober 2014 pukul 00.52. 
Olsen, S.E., Tangstad, M., and Lindstad, T., 1995. The ferromanganese process - Material and energy balance, Infacon 7, Trondheim, Norway, $621-630$.

Olsen, S.E., Tangstad, M., dan Lindstad, T., 2007. Production of manganese ferroalloys, Tapir Academic Press, Trondheim - Norwegia, 205 $-213$.

Peraturan Menteri Energi dan Sumber Daya Mineral Republik (mangan menguntit industri baja, 2008) Indonesia, Nomor : 1 Tahun 2014 tentang Peningkatan Nilai Tambah Mineral melalui Kegiatan Pengolahan dan Pemurnian Mineral, Lampiran I (Batasan Minimum Pengolahan dan Pemurnian Komoditas Tambang Mineral Logam), Hal : 5.

Rosenqvist, T., 2004. Principles of extractive metallurgy, $2^{\text {nd }}$ ed. Tapir Academic Press, Trondheim, Norwegia, 237-382.
Supriyatna, Y.I., 2013. Studi pengolahan bijih mangan menjadi ferromangan menggunakan tanur busur listrik satu fase, Jurnal Teknologi Mineral dan Batubara, Vol.9, No.1, 50-60.

Undang-Undang Republik Indonesia No 4 tahun 2009 tentang Pertambangan Mineral dan Batubara, Kewajiban bagi Pemegang Izin Usaha Pertambangan (IUP) dan Izin Usaha Pertambangan Khusus (IUPK) untuk melakukan peningkatan nilai tambah produk tambang mineral dan batubara melalui kegiatan pengolahan dan pemurnian, Hal : 21.

Welebeloved, D.B., Craven, P.M., and Waudby J.W., 2012. Ulmann's, encyclopedia of industrial chemistry: Manganese and manganese alloys, Willey - VCH Verlag $\mathrm{GmbH} \& \mathrm{Co}$, Weinheim, Vol.22, 185-193. 
